Acta Theriologica 44 (1): 1-13, 1999.

PL ISSN 0001-7051

\title{
Habitat and food preferences in a guild of insectivorous mammals in the Western Pyrenees
}

\author{
Enrique CASTIÉN and Joaquim GOSÁLBEZ
}

Castién E. and Gosálbez J. 1999. Habitat and food preferences in a guild of insectivorous mammals in the Western Pyrenees. Acta Theriologica 44: 1-13.

The use of trophic and spatial resources in a guild composed of five species of insectivorous mammals (Galemys pyrenaicus, Talpa europaea, Neomys fodiens, Sorex coronatus, and Sorex minutus) was studied. The characteristics of the macrohabitat were studied based on data from trap lines. Those pertaining to the microhabitat were examined through a study of the sites where each animal was caught. The diet was studied by analysis of the digestive tract as well as the availability of resources in various microhabitats. The results show a high level of segregation in the use of trophic resources. The microhabitat used on the ground surface has a low level of segregation among the shrews. A comparison of the diet of each species with the results from the invertebrate sampling carried out in different microhabitats (water, subsoil, humus, ground surface) shows that there is a relation between the food consumed and its availability in the microhabitats utilised by each species. This study suggests that the coexistence among the insectivorous species studied may be explained by the use of the microhabitat and diet segregation. The differences in diet would be a consequence of the use of different microhabitats.

Servicio de Conservación de la Biodiversidad, Gobierno de Navarra, C./ Alhóndiga 1, 31002 Pamplona, Spain (EC); Departament de Biología Animal, Facultat de Biologia, Universitat de Barcelona, Avgda. Diagonal 645, 08028 Barcelona, Spain (JG)

Key words: insectivorous guild, Sorex, Neomys, Talpa, Galemys, microhabitat, segregation, diet, interspecific competition

\section{Introduction}

The main arguments leading to an explanation for the coexistence among species of the same guild, are based on the use of the trophic, spatial, and temporal resources, which are considered to be the components having the greatest influence in niche structuralization (Pianka 1973, Schoener 1974). Terrestrial insectivorous mammals have a polyphasic activity rhythm due to their high metabolic requirements (Buchalczyk 1972, Buschinger and Witte 1976, Genoud 1984, 1988, Aitchison 1987, Stone 1987, Lardet 1988). For this reason it is generally impossible to identify interspecies differences in activity time. Rather, studies focus on the use of trophic and spatial resource dimensions within the community. Different theories have attempted to explain the coexistence among the species of terrestrial insectivores. Some authors suggest that differences in prey size may be an 
important factor (Butterfield et al. 1981, Yalden 1981, Churchfield 1984, Ryan 1986). Other authors indicate that habitat use may be an important factor in niche partitioning. Neet and Hausser (1990) demonstrated segregation in habitat use in the contact zone between Sorex coronatus and Sorex araneus. Studies on the relationship between Sorex araneus and Sorex minutus have revealed differences in the use of different soil levels (Croin Michielsen 1966, Ellenbroek and Hamburger 1991). Some authors have identified different preferences in the types of prey consumed, for example in diets of Sorex araneus, Sorex minutus and Neomys fodiens (Churchfield 1984). Whitaker and French (1984) detected differences in the types of prey consumed by six species of shrews in New Brunswick, which would also suggest differences in the use of the microhabitat and selection of prey size.

Coexistence patterns among insectivores in a given community are still relatively unknown. In a shrew community in the Siberian taiga, Churchfield (1994) found marked differences in prey size, which were related to the sizes of shrew species. She also suggested that trophic specialisation reduced competition in the community and attributed some of the differences found in the diet to microhabitat specialisation by each species. Terrestrial insectivorous mammals feed on prey which are small in comparison to their own size. Schoener (1974) believes that animals that prey on relatively small sized prey tend to be segregated more by habitat utilisation than by diet.

This paper analyses the use of trophic and spatial resources in a guild of five species of insectivorous mammals (Galemys pyrenaicus Geoffroy, 1811, Talpa europaea Linnaeus, 1758, Neomys fodiens Pennant, 1771, Sorex coronatus Millet, 1828 and Sorex minutus Linnaeus 1766) living sympatrically in the forest of the Quinto Real Massif (Western Pyrenees). The purpose of this study is to review the importance of diet, prey size and habitat use in coexisting terrestrial insectivorous mammals belonging to a specific guild.

\section{Material and methods}

This study was carried out in the Quinto Real Massif $\left(43^{\circ} 02^{\prime} \mathrm{N}, 2^{\circ} 14^{\prime} \mathrm{E}\right.$, Western Pyrenees, north of the Iberian Peninsula) at the altitudes of $660-1000 \mathrm{~m}$. The mean annual rainfall in the study area is $2138 \mathrm{~mm}$. The lowest and highest monthly average temperatures were registered in January $\left(2.9^{\circ} \mathrm{C}\right)$ and August $\left(16.6^{\circ} \mathrm{C}\right)$, respectively. The mean annual temperature is $8.8^{\circ} \mathrm{C}$.

Five main macrohabitats could be distinguished in the area. A large part was covered by an acidophilic type beechwood forest Saxifrago hirsutae-Fagetum sylvaticae (Braun-Blanquet 1967). Clearings in the forest due to cutting were occupied by moorlands Daboecio cantabricae-Ulicetum cantabrici (Braun-Blanquet 1967). The edges of the woods were covered with bramble patches Rubo ulmfolii-Tametum communis (Tüxen and Oberdorfer 1958) and megaphorbia composed of Valerianetum pyrenaicae (Rivas-Martínez et al. 1984), which occurred continuously depending on the edaphic humidity and availability of light. The vegetation on the riverbanks was of the Hyperico androsaemi-Alnetum association (Braun-Blanquet 1967).

Data were collected on a total of 354 insectivores (49 Galemys pyrenaicus, 73 Talpa europaea, 51 Neomys fodiens, 31 Sorex minutus, and 250 Sorex coronatus). The animals were captured using 
snap-traps (16,721 traps-night), live-traps (3,000 traps-night), wire-mesh eel traps in streamlets (120 traps-nirht), pitfall traps (470 traps-night) and tweezers in underground galleries. Sampling was carried out monthly in all the macrohabitats over a two-year period in order to have a balanced represertation in time and space. Trapped animals were immediately killed in compliance with the international policies of animal care and welfare. All of the animals caught are in storage at the Centro ce Biodiversidad Animal of the Universidad de Barcelona and are available for use in different research projects seeking to maximise the use of the material.

Mac:ohabitats were sampled along snap-trap lines placed in each of the five macrohabitats defined. The lines consisted of 30-300 snap-traps that remained in place overnight. The type of vegetation was recorded in a band of approximately $3 \mathrm{~m}$ on either side of each snap-trap line. This made it possible to compare the use of the macrohabitat by terrestrial species. The wire-mesh eel traps placed in the water and the tweezers in the underground galleries have provided information on the soecies that inhabit these media.

Characterisation of the ground surface microhabitat used by each species caught on the surface was carried out by preparing a profile of the vegetation in a $3 \mathrm{~m}$ radius around each of the capture sites (Sryder and Best 1988). The profile was drawn up by taking 10 random cover measurements with a tape measure placed vertically over the ground and recording the contact height of each type of vegetation. Data were collected on the type of substrate and vegetative cover at different height intervals, which define, as a whole, the main variables used in habitat studies (Boitani 1984, Doyle 1987, Sryder and Best 1988). Vegetation was grouped into 14 different types: Fagus sylvatica, Alnus glutinosa, Corylus avellana, Salix sp., other trees, Rubus sp., heathers, other brushwood, Pteridium aquilinum, herbaceous meadowlands, other herbaceous vegetation, branches, mosses and litter. For each vegetation type, heights were divided into 5 intervals: $0-5 \mathrm{~cm}, 6-10 \mathrm{~cm}, 11-25 \mathrm{~cm}, 26-50 \mathrm{~cm}$, 51-100 cm. Profiles were drawn up similar to those of MacArthur and MacArthur (1961), giving a more detailed description of the vegetation closest to the surface, following Abramsky et al. (1985) and Snyder and Best (1988). The distance to the nearest accessible water zone was also recorded at each capture point. The breadth of the spatial niche $\left(\mathrm{B}_{i}{ }^{\prime}\right)$ and the overlap of the spatial niche $\left(\mathrm{G}_{\mathrm{ih}}\right)$ were calculated using the Colwell and Futuyma indices (1971).

The diets and trophic niche breadth of the guild species were described in Castién (1995) and Castién and Gosálbez $(1994,1995 a, b, c)$. In order to verify this, the stomach and intestinal contents were analyzed. The breadth of the trophic niche $(\mathrm{H})$ was calculated using the formula of Brillouin (Pielou 1966). The overlap of the trophic niche $\left(\mathrm{T}_{\mathrm{ih}}\right)$ was estimated with the Colwell and Futuyma (1971) indices.

Available trophic resources were sampled using several methods. Oligochaetes, were sampled monthly (6 samples of $0.5 \mathrm{~m}^{2}$ each month) for a year in a clearing in the woods by means of formaldehyde extraction following Jesús et al. (1981). Moreover in the month of April, 6 samples, were obtained in each of 5 macrohabitats using the same method. To complement the study, manual searches were conducted in the same sampling areas for other invertebrates on the ground. Fluvial macroinvertebrates were sampled quarterly for a year ( 8 samples each season) using a $929.4 \mathrm{~cm}^{2}$ Surber net (Southwood 1966, Mason 1984) in a fixed section of the stream. Ground surface arthropods were sampled in beech forest and moorlands monthly for a year by placing pitfall traps buried flush with the ground ( 15 pitfall traps $\times 10$ night each month in both macrohabitats). Monthly samples of humus invertebrates $\left(0.5 \mathrm{~m}^{2}\right.$ each month for a year) were extracted from the beech forest and moorlands by desiccation in Berlese funnels (Southwood 1966). Samples of humus were supplemented by manual extraction of oligochaetes from a similar surface, which improved data published earlier (Castién and Gosálbez 1995b). Monthly sampling manual with tweezers was also carried out for a year as well as on the ground underneath fallen tree trunks within the forest (total area of $4 \mathrm{~m}^{2}$ each month).

The relative importance of trophic resources was estimated as the total frequencies of prey found in sampling efforts in each type of microhabitat (subsoil, water, humus and ground surface). 
The mean prey length in the diet of each mammal species was determined by measuring a collection of invertebrates, consisting of the same proportion of each systematic group and development stage as found in the diet. The prey length for Galemys pyrenaicus was determined by measuring whole prey found in the digestive tract (Castién and Gosálbez 1995c).

The relative abundance of invertebrates in the field and their proportion in the diet was compared by means of the similarity coefficient $C=2 w / a+b$ (Ryan 1986), where $w$ - the sum of the lowest of the two pairs of values (field-diet), in percentages, for each type of invertebrate, $a$ - the sum of all the values in percentage, for the diet of the species, and $b$ - the sum of all the values, in percentage, for invertebrates found in the field.

\section{Results}

\section{Use of space: macro- and microhabitats}

Galemys pyrenaicus was captured exclusively in water courses and Talpa europaea was only collected in underground galleries. Talpa europaea is the only insectivorous species that inhabits meadow lands on a permanent basis. Both species are considered to have specific habitats, which differ greatly from the rest of the community. The three shrew species were caught in the different macrohabitats in varying abundance (Table 1). However they all are most abundant in the gallery formation and secondly in the bramble patches. S. coronatus and $S$. minutus have been caught in all the macrohabitats, whereas $N$. fodiens was not found in the moorlands or beech forest.

The other three species were compared in terms of how they use the ground surface with reference to the vegetation profiles, which were defined by the capture sites of each species (Table 2). Following are the spatial niche breadth ( $\mathrm{B}_{i}^{\prime}$ ) values for each species: 0.80 for Neomys fodiens, 0.81 for Sorex coronatus, and 0.83 for $S$. minutus. The high values found suggest that the all-available vegetative structures are extensively used by all these species.

The mean spatial overlap in the group studied is high: $\mathrm{G}_{\mathrm{ih}}=0.65(\mathrm{SE}=0.06$ $n=3$ ). If we compare the different pairs of species, the resulting values show some

Table 1. Number of captures and relative abundance (captures/100 traps-night) determined by means of trap lines in each of the macrohabitats distinguished in Quinto Real. $n$ - captures, \% $n-$ captures/100 traps-night.

\begin{tabular}{|c|c|c|c|c|c|c|c|c|c|c|}
\hline \multirow{3}{*}{ Species } & \multicolumn{10}{|c|}{ Macrohabitat type } \\
\hline & \multicolumn{2}{|c|}{ Beech forest } & \multicolumn{2}{|c|}{ Moorland } & \multicolumn{2}{|c|}{ Bramble patch } & \multicolumn{2}{|c|}{ Gallery formation } & \multicolumn{2}{|c|}{ Meadowa } \\
\hline & $n$ & $\% n$ & $n$ & $\% n$ & $n$ & $\% n$ & $n$ & $\% n$ & $n$ & $\% n$ \\
\hline S. coronatus & 3 & 0.26 & 10 & 1.17 & 79 & 1.17 & 92 & 1.35 & 0 & 0 \\
\hline S. minutus & 0 & 0 & 0 & 0 & 4 & 0.06 & 6 & 0.09 & 0 & 0 \\
\hline$N$. fodiens & 0 & 0 & 0 & 0 & 17 & 0.25 & 32 & 0.47 & 0 & 0 \\
\hline $\begin{array}{l}\text { Total number } \\
\text { of trap-nights }\end{array}$ & \multicolumn{2}{|c|}{1106} & \multicolumn{2}{|c|}{851} & \multicolumn{2}{|c|}{6748} & \multicolumn{2}{|c|}{6811} & \multicolumn{2}{|c|}{1186} \\
\hline
\end{tabular}


Table 2. Mean vegetation coverage in each vertical strata, constructed in the $3 \mathrm{~m}$ radius around each capture site, of three shrew species active mainly on the ground surface. $n$-sample sizes.

\begin{tabular}{|c|c|c|c|c|c|c|c|c|c|}
\hline $\begin{array}{l}\text { Height of } \\
\text { strata } \\
(\mathrm{cm})\end{array}$ & $\begin{array}{c}\text { Fagus } \\
\text { sylvaticus }\end{array}$ & $\begin{array}{l}\text { Other } \\
\text { trees }\end{array}$ & $\begin{array}{l}\text { Other } \\
\text { brush- } \\
\text { wood }\end{array}$ & Heather & $\begin{array}{l}\text { Pteridium } \\
\text { sp. }\end{array}$ & $\begin{array}{l}\text { Mead- } \\
\text { ows }\end{array}$ & $\begin{array}{c}\text { Other } \\
\text { herba- } \\
\text { ceous } \\
\text { vege- } \\
\text { tation }\end{array}$ & $\begin{array}{l}\text { Dead } \\
\text { vege- } \\
\text { tation }\end{array}$ & $\begin{array}{c}\text { Total } \\
\text { percent- } \\
\text { age } \\
\text { of } \\
\text { coverage }\end{array}$ \\
\hline \multicolumn{10}{|c|}{ Sorex minutus $(n=27)$} \\
\hline $51-100$ & 0.63 & 0.32 & 8.25 & 0.63 & 5.72 & 0 & 3.49 & 0.95 & 19.99 \\
\hline $26-50$ & 0 & 0 & 17.82 & 1.71 & 6.85 & 2.05 & 6.85 & 1.37 & 36.65 \\
\hline $11-25$ & 0 & 0 & 15.01 & 7.07 & 3.21 & 2.89 & 9.31 & 3.53 & 41.02 \\
\hline $6-10$ & 0 & 0 & 3.85 & 0.67 & 2.45 & 5.97 & 8.07 & 6.31 & 33.32 \\
\hline $0-5$ & 0 & 0 & 1.43 & 7.89 & 0.36 & 10.76 & 8.97 & 50.22 & 79.63 \\
\hline \multicolumn{10}{|c|}{ Sorex coronatus $(n=207)$} \\
\hline $51-100$ & 0.36 & 1.01 & 8.14 & 0.24 & 3.18 & 0.98 & 1.55 & 0.57 & 16.03 \\
\hline $26-50$ & 0.26 & 0.82 & 13.26 & 2.23 & 2.62 & 4.42 & 5.02 & 1.71 & 30.34 \\
\hline $11-25$ & 0.12 & 0.21 & 11.31 & 3.75 & 2.87 & 10.72 & 10.55 & 2.67 & 42.2 \\
\hline $6-10$ & 0 & 0.09 & 5.64 & 3.41 & 2.32 & 12.69 & 10.26 & 5.51 & 39.92 \\
\hline $0-5$ & 0 & 0.05 & 0.32 & 2.99 & 1.83 & 20.54 & 11.50 & 41.46 & 78.69 \\
\hline \multicolumn{10}{|c|}{ Neomys fodiens $(n=51)$} \\
\hline $51-100$ & 0.5 & 3.63 & 14.23 & 0 & 4.63 & 0.33 & 4.3 & 5.13 & 32.75 \\
\hline $26-50$ & 0.32 & 1.79 & 17.1 & 1.13 & 2.11 & 4.88 & 8.8 & 8.14 & 44.27 \\
\hline $11-25$ & 0.17 & 0.17 & 9.68 & 0.33 & 1.84 & 12.85 & 9.17 & 9.51 & 43.72 \\
\hline $6-10$ & 0 & 0 & 3.35 & 0.37 & 0.73 & 16.74 & 6.51 & 8.37 & 36.07 \\
\hline $0-5$ & 0 & 0 & 1.18 & 0 & 0.39 & 23.14 & 10.58 & 44.51 & 79.8 \\
\hline
\end{tabular}

differences (Neomys fodiens - Sorex minutus: 0.53, Neomys fodiens - Sorex coronatus: 0.69 , Sorex minutus - Sorex coronatus: 0.74 ). This points mainly to a certain differentiation in the microhabitat of Neomys fodiens as compared to the other two species. This differentiation is linked to the greater amount of cover in the higher bushy strata and to a more marked presence of herbaceous vegetation in the habitat used by $N$. fodiens in contrast to the other two species.

The mean distance from the capture site $( \pm \mathrm{SE})$ to accessible water for each species was: $16.61 \pm 1.73 \mathrm{~m}(n=224)$ for $S$. coronatus, $22.31 \pm 6.02 \mathrm{~m}(n=30)$ for $S$. minutus, $9.19 \pm 2.28 \mathrm{~m}(n=50)$ for $N$. fodiens. The comparisons between pairs of species using the Student $t$ test show significant differences $(p<0.05)$ in all cases. $N$. fodiens is the species that lives closest to the water and $S$. minutus is the one that lives at the greatest mean distance.

\section{Use of trophic resources}

Galemys pyrenaicus had a diet based on aquatic larvae of Diptera, Trichoptera, Plecoptera and Ephemeroptera (Fig. 1). It had the highest trophic specialisation 


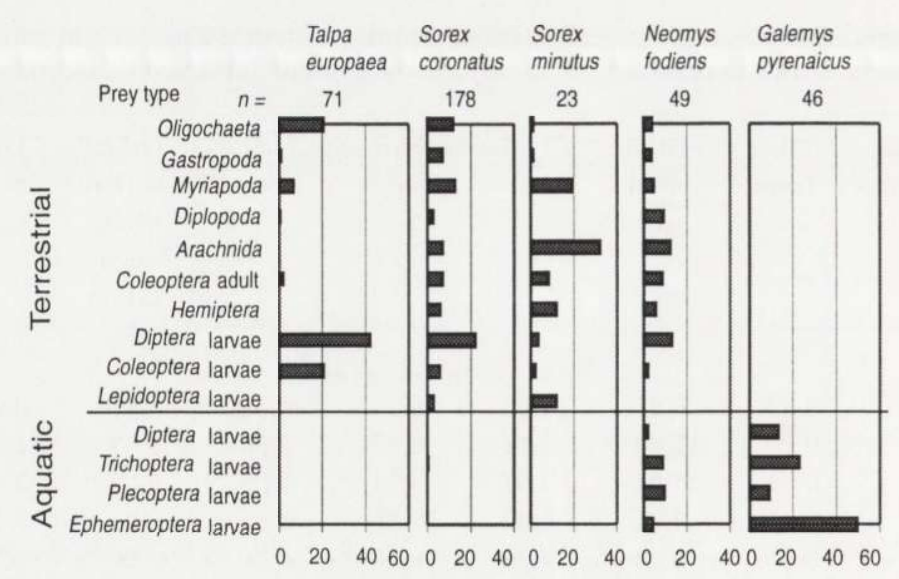

Fig. 1. Frequency of numerical occurrence in percentages of the most important types of food in the diet of five species of insectivores. Data for Galemys pyrenaicus from Castién and Gosálbez 1995c; for Talpa europaea from Castién and Gosálbez 1995a; for Sorex coronatus from Castién and Gosálbez 1995b; for Sorex minutus from Castién and Gosálbez 1994; for Neomys fodiens from Castién 1995.

(Table 3). The diet of Talpa europaea consisted mainly of Diptera larvae, oligochaetes, (mostly medium or large sized Lumbricidae) and Coleoptera larvae (Fig. 1). The low $\mathrm{H}$ value indicates a certain amount of specialization (Table 3). Sorex coronatus fed mainly on Diptera larvae, and also consumed a high percentage of gastropods, myriapods and oligochaetes, mainly small surface earthworms (Fig. 1). Its trophic niche breadth was wide (Table 3). The diet of Sorex minutus consisted of Myriapoda, Araneae + Opiliones, adult Coleoptera, Hemiptera and Lepidoptera larvae (Fig. 1). It showed a moderate trophic niche amplitude value due to a greater specialisation than in the previous species (Table 3). Neomys fodiens fed on an extensive list of resources including terrestrial and aquatic animals. The following species were eaten in high proportions: the Diplopoda, Araneae + Opiliones, adult Coleoptera, larvae of Diptera, Tricoptera and Pleco-

Table 3. Trophic niche breadth $(\mathrm{H})$ values for each insectivore species in seasonal and annual diets. Empty cells indicate insufficient sample size $(<6$ digestive tracts analyzed). $\mathrm{H}$ is the value of the diversity (formula of Brillouin, Pielou 1966) calculated as of the diet of each species.

\begin{tabular}{|c|c|c|c|c|c|}
\hline \multirow{2}{*}{ Species } & \multicolumn{4}{|c|}{ Season } & \multirow{2}{*}{$\begin{array}{c}\text { Annual } \\
\text { total }\end{array}$} \\
\hline & Autumn & Winter & Spring & Summer & \\
\hline Galemys pyrenaicus & 2.08 & 2.02 & 1.75 & 1.69 & 1.99 \\
\hline Talpa europaea & 2.19 & 2.21 & 2.04 & 2.24 & 2.27 \\
\hline Neomys fodiens & 3.50 & 3.89 & - & 3.29 & 3.72 \\
\hline Sorex minutus & - & - & - & - & 2.92 \\
\hline Sorex coronatus & 3.47 & 3.18 & 3.29 & 3.71 & 3.69 \\
\hline
\end{tabular}


Table 4. Matrix of trophic overlap ( $\mathrm{T}_{\mathrm{ih}}$ ) between the insectivores of the Quinto Real Massif. $\mathrm{T}_{\mathrm{ih}}$ : Colwell and Futuyma (1971) indices of niche overlap (range $0-1$.).

\begin{tabular}{lcccc}
\hline Species & Galemys pyrenaicus & Talpa europaea & Neomys fodiens & Sorex minutus \\
\hline Talpa europaea & 0.002 & & & \\
Neomys fodiens & 0.34 & 0.45 & & \\
Sorex minutus & 0.002 & 0.27 & 0.37 & \\
Sorex coronatus & 0.01 & 0.78 & 0.57 & 0.44 \\
\hline
\end{tabular}

ptera (Fig. 1). This is a species having the most generalized diet with a balanced intake of all the invertebrate groups.

The mean trophic overlap of the community studied (Table 4 ) is $\mathrm{T}_{\mathrm{ih}}=0.325$ $(\mathrm{SE}=0.08, n=10)$. The maximum overlap values are seen in the pairs of the following species: Neomys fodiens-Sorex coronatus and Sorex coronatus-Talpa europaea. The latter two species consumed a large amount of oligochaetes. Sorex coronatus, however, fed on the minute oligochaetes from the humus layer (Genus Dendrobaena), while Talpa europaea ate edaphic oligochaetes (Genus Lumbricus and Allolobophora), thus the trophic segregation between the two insectivores was higher in reality (Castién 1994). For the remaining species the $\mathrm{T}_{\text {ih }}$ values indicate that there is little trophic overlap.

Table 5. Seasonal trophic overlap ( $\mathrm{T}_{\mathrm{ih}}$ ) matrices for insectivores of the Quinto Real. Insufficient seasonal samples were available for Sorex minutus. $\mathrm{T}_{\text {ih }}$ as in Table 4.

\begin{tabular}{lllc}
\hline Species & Galemys pyrenaicus & Talpa europaea & Neomys fodiens \\
\hline $\begin{array}{l}\text { Autumn } \\
\text { Talpa europaea }\end{array}$ & 0.01 & & \\
$\quad$ Neomys fodiens & 0.21 & 0.25 & 0.54 \\
Sorex coronatus & 0.01 & 0.57 & \\
Winter & & & \\
Talpa europaea & 0.00 & 0.36 & \\
Neomys fodiens & 0.34 & 0.48 & \\
Sorex coronatus & 0.004 & & \\
Spring & & & \\
Talpa europaea & 0.00 & 0.002 & \\
Neomys fodiens & 0.64 & 0.54 & \\
Sorex coronatus & 0.02 & & \\
Summer & & 0.32 & \\
Talpa europaea & 0.002 & 0.54 & \\
Neomys fodiens & 0.33 & & \\
Sorex coronatus & 0.02 & & \\
\hline
\end{tabular}


Table 6. The relative importance of the main trophic resources, as measured in relative frequencies (\%), sampled in each microhabitat. Only those items representing over $5 \%$ of the prey consumed by some of the insectivorous mammal species are shown. The species in each medium are included. * - scarce, ${ }^{* *}$ - abundant, "-" - not found.

\begin{tabular}{lccccc}
\hline \multirow{2}{*}{ Prey taxa } & \multicolumn{5}{c}{ Microhabitats } \\
\cline { 2 - 6 } & Water & Subsoil & Humus & Surface & Fallen logs \\
\hline Oligochaeta & - & 72.6 & 14.0 & - & $*$ \\
Gastropoda & - & - & $* *$ & $* *$ & $* *$ \\
Chilopoda & - & 2.1 & 16.3 & 3.0 & 29.5 \\
Diplopoda & - & - & 16.1 & 5.2 & 9.6 \\
Araneae & - & - & 1.8 & 10.2 & 13.6 \\
Opiliones & - & - & 1.5 & 0.5 & 7.4 \\
Coleoptera adult & - & 3.2 & 5.1 & 16.6 & 5.2 \\
Coleoptera larvae & - & 9.5 & 2.1 & 0.9 & - \\
Diptera larvae & 11.6 & 9.5 & 5.2 & - & 5.7 \\
Lepidoptera larvae & - & 1.0 & 2.1 & 1.6 & 0.5 \\
Hemiptera & - & - & 3.5 & 0.7 & 0.7 \\
Hymenoptera & - & $* *$ & 1.0 & 18.6 & 5.2 \\
Ephemeroptera larvae & 23.5 & - & - & - & - \\
Plecoptera larvae & 6.2 & - & - & - & - \\
Trichoptera larvae & 10.4 & & & & \\
\hline
\end{tabular}

The matrices of seasonal trophic overlap (Table 4) do not exhibit, on the whole, very high values. The seasonal values of $\mathrm{T}_{\mathrm{ih}}$ between Sorex coronatus and Talpa europea are appreciably lower than the value obtained for the annual diet as a whole. The overlap level between Sorex coronatus and Neomys fodiens was also lower in the seasonal comparisons than in the annual diet as a whole. The overlap between these two species varied depending on the season, with levels remaining constant and moderate during the summer and autumn and dropping in winter and especially in spring. This decrease is due to a noticeable rise in prey of aquatic

Table 7. Similarity coefficients, $C$ (Ryan 1986) calculated between the prey found in the digestive tracts and the invertebrates caught sampled in the different microhabitats.

\begin{tabular}{lccccc}
\hline \multirow{2}{*}{ Species } & \multicolumn{5}{c}{ Prey from: } \\
\cline { 2 - 6 } & Fluvial benthos & Subsoil & Humus & Fallen logs & Ground surface \\
\hline Galemys pyrenaicus & 0.55 & 0.10 & 0.06 & 0.01 & 0.01 \\
Talpa europaea & 0.16 & 0.44 & 0.35 & 0.24 & 0.13 \\
Sorex minutus & 0.07 & 0.15 & 0.43 & 0.55 & 0.31 \\
Sorex coronatus & 0.17 & 0.36 & 0.59 & 0.43 & 0.27 \\
Neomys fodiens & 0.39 & 0.21 & 0.44 & 0.40 & 0.28 \\
\hline
\end{tabular}


origin, which coincides with an increase in the overlap index between Neomys fodiens and Galemys pyrenaicus.

The available trophic resources varied in each microhabitat (Table 6). For Galemys pyrenaicus (Table 7) the similarity coefficient was the highest for aquatic benthos. The diet of Talpa europaea had the greatest similarity with the subsoil sample. The diet of Sorex minutus showed the highest similarity with invertebrates from the ground surface, humus, and under fallen logs, with its highest value being under fallen logs. The diet of Sorex coronatus exhibited high similarity coefficients with all the terrestrial samples, and particularly with the humus sample. Neomys fodiens had relatively high values in all the microhabitats except ground surface and subsoil.

The mean $( \pm$ SE) prey length for each species is the following: $7 \pm 0.2 \mathrm{~mm}$ $(n=213)$ for Galemys pyrenaicus, $39 \pm 10.3 \mathrm{~mm}(n=100)$ for Talpa europaea, $9 \pm 0.9 \mathrm{~mm}(n=98)$ for Neomys fodiens, $9 \pm 0.6 \mathrm{~mm}(n=145)$ for Sorex minutus, $13 \pm 1.2 \mathrm{~mm}(n=92)$ for Sorex coronatus. The greatest size differences corresponded to the different amounts of Lumbricidae present in the diet as well as to the average length of the different species of Lumbricidae consumed. A comparison of the mean length of the prey using the $U$ of Mann-Whitney test, indicates that there were significant differences $(p<0.05)$ in all the pairs of species that were compared, except in the comparison between species that do not consume oligochaetes: Sorex minutus, Neomys fodiens and Galemys pyrenaicus.

\section{Discussion}

Galemys pyrenaicus uses mainly the aquatic medium while Talpa europaea lives in the subsoil. Therefore, these species are clearly differentiated with respect to microhabitat use. The segregation of the three species of shrews has little importance in terms of the macrohabitat. All three are more abundant in gallery formations and in bramble patches. It is only $N$. fodiens which exhibits a certain individuality in relation to its macrohabitat. This preference may be related to the greater abundance of invertebrates in the gallery formations and bramble patches (Doyle 1990, Castién 1994). The distance from the capture site to accessible water also marks some differences. $N$. fodiens lives closer to water than the other two species of shrews. However, these differences are not substantial. Therefore, it would be possible to suggest that the ground surface microhabitat does not clearly differentiate shrew species. This agrees with Gurnell's (1985) and Canova and Fasola's (1991) results from surface sampling. However, not only are these species active on the ground surface, Sorex coronatus is thought to use underground burrows a lot of the time in a similar way to Sorex araneus (Castién and Gosálbez 1995b), whereas Sorex minutus uses the surface to a greater extent (Croin Michielsen 1966, Ellenbroek and Hamburger 1991). Neomys fodiens carries 
out part of its activity in water courses, especially when ground resources are scarce (Castién 1995).

The diets of the insectivores of Quinto Real do not differ substantially from diets reported in other locations (Skoczeń 1966, Oppermann 1968, Pernetta 1976, Wołk 1976, Niethammer 1977, 1978, Grainger and Fairley 1978, Butterfield et al. 1981, Churchfield 1984, Du Pasquier and Cantoni 1992). This insectivore guild has high segregation in the use of trophic resources, both in the whole year (Table 4) and seasonal analyses (Table 5). The exception was Neomys fodiens, which has variable trophic overlaps with Galemys pyrenaicus and Sorex species throughout the year (Table 5).

These differences in feeding agree with other data regarding the diet of sympatric shrews (Ryan 1986) and coincide with Churchfield's (1984) results for Neomys fodiens, Sorex minutus and S. coronatus. The latter, however, concluded that there is high trophic overlap among the three species. This is probably due to the fact that she analysed faeces, and therefore, is limited in quantitative estimates.

The average prey size differs among most species, but these differences may be attributed mostly to the quantity and genera of the Lumbricidae that make up the diet. Differences in prey size are considered to be a consequence of the type of prey, which could be related, in turn, to the microhabitat utilized by each insectivore rather than a differential selection in terms of prey size. This reasoning is in keeping with the fact that some studies have found differences (Ryan 1986, Yalden 1981, Butterfield et al. 1981, Churchfield 1994) and others have not (Churchfield 1984). The relation between prey size and the abundance of Lumbricidae coincides with the results given by Churchfield (1994).

If we observe the composition of invertebrate fauna in the different microhabitats, it is evident that prey are not equally distributed among them. Similarly, the diet of each insectivore is closely related to the invertebrate fauna of certain microhabitats (Table 5). These microhabitats roughly coincide with those previously reported as the most commonly used by each species (Croin Michielsen 1966, Hausser 1990, Hutterer 1990, Spitzenberger 1990, Juckwer 1990, Niethammer 1990, Ellenbroek and Hamburger 1991).

Churchfield (1994) found differences in the trophic niche in a community of Siberian shrews, which were linked to the species size and probably to the microhabitat used. Concomitantly, our results suggest that the diet differentiation among the insectivore species studied may be essentially attributed to the vertical segregation in the use of microhabitat structural components (subsoil, water, humus and ground surface). Galemys pyrenaicus gets its foods from the water medium; Talpa europea depends on the subsoil. Sorex coronatus feeds mainly within the humus layer, probably making the greatest use of micromammal burrows which are spread out over the upper layer of the ground. Sorex minutus basically uses the surface resources. Neomys fodiens alternates between the ground and water resources, depending on the relative availability of food. 
Moreover the three species of shrews show a slight difference in the surface microhabitat. This concurs with Schoener's (1974) generalisation that groups having a small food type relative to their size (microphages) tend to segregate in habitat rather than diet.

Thus, it appears that the difference in microhabitat use is the primary factor enabling the coexistence of small insectivorous mammals in guilds. Churchfield (1994) suggested that shrews choose their diets in a random and opportunistic manner. Our research indicates that the five species studied confirm this pattern.

Acknowledgements: The authors would like to thank I. Leránoz for his collaboration in the fieldwork, Dr J. Guitián (University of Santiago de Compostela) and Dr J. A. Donázar (Biological Station of Doñana) for their valuable suggestions in the preparation of the original manuscript.

\section{References}

Abramsky Z., Rosenzweig M. L. and Brand S. 1985. Habitat selection of Israel desert rodents: comparison of a traditional and a new method of analysis. Oikos 45: 79-88.

Aitchison C. W. 1987. Winter energy requirements of soricine shrews. Mammal Review 17: 25-38

Boitani A. L. L. 1984. Microhabitat structure of two rodent species, Apodemus sylvaticus and Mus musculus, in Mediterranean landscape. Atti I Seminario Associazione Teriologica Romana, Roma: $143-161$.

Braun-Blanquet J. 1967. Vegetationsskizzen aus dem Baskenland mit Ausblicken auf das weitiere Ibero-Atlantikum. II Teil. Vegetatio 14: 1-126.

Buchalczyk A. 1972. Seasonal variations in the activity of shrews. Acta Theriologica 17: 221-243,

Buschinger A. and Witte G. R. 1976. Untersuchungen zur Periodik der lokomotorischen Aktivität des europäischen Maulwurfs (Talpa europaea L.) unter natürlichen Bedingungen. Bonner zoologische Beitrage 27: 20 .

Butterfield J., Coulson J. C. and Wanless S. 1981. Studies on the distribution, food, breeding biology and relative abundance of the Pygmy and Common shrews Sorex minutus and $S$. araneus) in upland areas of northern England. Journal of Zoology 195: 169-180.

Canova L. and Fasola M. 1991. Communities of small mammals in six biotopes of northern Italy. Acta Theriologica 36: 73-86.

Castién E. 1994. Estudio bioecológico de los micromamíferos (Insectivora y Rodentia) de un hayedo acidófilo. Quinto Real. Navarra. Tesis Doctoral, Universidad de Barcelona, Barcelona: 1-668.

Castién E. 1995. The diet of Neomys fodiens in the Spanish western Pyrenees. Folia Zoologica 44: $51-58$.

Castién E. and Gosálbez J. 1994. La dieta alimenticia de Sorex minutus (Linnaeus, 1766) en el Pirineo occidental norte de la península Ibérica. Doñana Acta Vertebrata 21: 53-59.

Castién E. and Gosálbez J. 1995a. Caractérisation de la niche trophique de Talpa europaea (Linnaeus, 1758) dans les Pyrénées occidentales (nord de la Péninsule Ibérique). Mammalia 59: 43-50.

Castién E. and Gosálbez J. 1995b. Diet of Sorex coronatus in the western Pyrenees. Acta Theriologica 40: $113-121$.

Castién E. and Gosálbez J. 1995c. Diet of Galemys pyrenaicus (Geoffroy, 1811) in the north of the Iberian peninsula. Netherland Journal of Zoology 45: 422-430.

Colwell R. K. and Futuyma D. J. 1971. On the measurement of niche breadth and overlap. Ecology 52: 567-576.

Croin Michielsen N. 1966. Intraspecific and interspecific competition in the shrews Sorex araneus L. and Sorex minutus L. Archives Néerlandaises de Zoologie 17: 73-174. 
Churchfield S. 1984. Dietary separation in three species of shrew inhabiting water-cress beds. Journal of Zoology 204: 211-228.

Churchfield S. 1994. Food niche overlap and ecological separation in a multi-species community of shrews in the Siberian taiga. Journal of Zoology 234: 105-124.

Doyle A. T. 1987. Microhabitat separation among Sympatric Microtines, Clethrionomys californicus, Microtus oregoni and M. richardsoni. American Midland Naturalist 118: 258-265.

Doyle A. T. 1990. Use of riparian and upland habitats by small mammals. Journal of Mammalogy 71: 14-23.

Du Pasquier A. and Cantoni D. 1992. Shifts in bentic macroinvertebrate community and food habits of the water shrew, Neomys fodiens (Soricidae, Insectivora). Acta Oecologica 13: 81-99.

Ellenbroek F. J. M. and Hamburger J. 1991. Interspecific interactions between the shrews Sorex araneus L. and Sorex minutus L. (Soricidae, Insectivora) and the use of habitat: A laboratory study. Netherland Journal of Zoology 41: 32-62.

Genoud M. 1984. Activity of Sorex coronatus (Insectivora, Soricidae) in the field. Zeitschrift für Säugetierkunde 49: 74-78.

Genoud M. 1988. Energetics strategies of shrews: ecological constraints and evolutionary implications. Mammal Review 18: 173-193.

Grainger J. P. and Fairley J. S. 1978. Studies on the biology of the Pygmy shrew, Sorex minutus, in the west of Ireland. Journal of Zoology 186: 109-141.

Gurnell J. 1985. Woodland rodents communities. [In: The ecology of woodlands rodents. Bank voles and wood mice. J. R. Flowerdew, J. Gurnell and J. H. W. Gipps, eds]. Oxford University Press, Oxford: $377-402$.

Hausser J., 1990. Sorex coronatus Millet, 1882. Schabrackenspitzmaus. [In: Handbuch der Säugetiere Europas. Band 3/1. J. Niethammer and F. Krapp, eds]. Akademische Verlagsgesellschaft, Wiesbaden: 279-286.

Hutterer R., 1990. Sorex minutus Linnaeus, 1766. Zwergsptzmaus. [In: Handbuch der Säugetiere Europas. Band 3/1. J. Niethammer and F. Krapp, eds]. Akademische Verlagsgesellschaft, Wiesbaden: 183-206.

Jesús J. B., Moreno A. G. and Díaz Cosín D. J. 1981. Lombrices de Tierra de la Vega de Aranjuez (España). I. Asociaciones. Revue d'Ecologie et Biologie du Sol 18: 507-519.

Juckwer E-A. 1990. Galemys pyrenaicus (Geoffroy, 1811). Pyrenäen-Desman. [In: Handbuch der Säugetiere Europas. Band 3/1. J. Niethammer and F. Krapp, eds]. Akademische Verlagsgesellschaft, Wiesbaden: 79-92.

Lardet J. P. 1988. Spatial behaviour and activity patterns of the water shrew Neomys fodiens in the field. Acta Theriologica 33: 293-303.

Mason C. F. 1984. Biologia de la contaminación del agua dulce. Alhambra, Madrid: 1-289.

MacArthur R. and MacArthur J. 1961. On bird species diversity. Ecology 42: 594-598.

Neet C. R. and Hausser J. 1990. Habitat selection in zones of parapatric contact between the Common shrew Sorex araneus and Millet's shrew Sorex coronatus. Journal of Animal Ecology 59: 235-250.

Niethammer J. 1977. Ein syntopes Vorkommen der Wasserspitzmaüse (Neomys fodiens und Neomys anomalus). Zeitschrift für Säugetierkunde 42: 1-6.

Niethammer J. 1978. Weitiere Beobachtungen über syntope Wasserspitzmaüse der Arten Neomys fodiens und Neomys anomalus. Zeitschrift für Säugetierkunde 43: 313-321.

Niethammer J., 1990. Talpa europaea Linnaeus, 1758. Maulwurf. [In: Handbuch der Säugetiere Europas. Band 3/1. J. Niethammer and F. Krapp, eds]. Akademische Verlagsgesellschaft, Wiesbaden: 99-133.

Oppermann J. 1968. Die Nahrung des Maulwurfs (Talpa europaea) in unterschiedlichen Lebensräumen. Pedobiologia 8: 59-74.

Pernetta J. C. 1976. Diets of the shrews Sorex araneus L. and Sorex minutus L. in Wytham grassland. Journal of Animal Ecology 45: 899-913. 
Pianka E. R. 1973. The structure of lizard communities. Annual Review of Ecology and Systematics 4: 53-74.

Pielou E. C. 1966. Species-diversity and pattern-diversity in the study of ecological succession. Journal of Theoretical Biology 10: 370-383.

Rivas-Martínez S., Díaz T. E., Prieto J. A. F., Loidi J. and Penas A. 1984. La Vegetación de la Alta Montaña Cantábrica. Los Picos de Europa. Ediciones Leonesas, León.

Ryan J. M. 1986. Dietary overlap in sympatric populations of pigmy shrews, Sorex hoyi, and masked shrews, Sorex cinereus, in Michigan. Cannadian Field-Naturalist 100: 225-228.

Schoener T. W. 1974. Resource partitioning in ecological communities. Science 185: 27-39.

Skoczen S. 1966. Stomach contents of the mole, Talpa europaea Linnaeus, 1758 from southern Poland. Acta Theriologica 11: 551-575.

Snyder E. and Best L. 1988. Dynamics of habitat use by small mammals in prairie communities. American Midland Naturalist 119: 128-136.

Southwood T. R. E. 1966. Ecological Methods. Chapman and Hall, Londres: 1-391.

Spitzenberger F. 1990. Neomys fodiens (Pennant, 1771). Wasserspitzmaus. [In: Handbuch der Säugetiere Europas. Band 3/1. J. Niethammer and F. Krapp, eds]. Akademische Verlagsgesellschaft, Wiesbaden: $334-374$

Stone R. D. 1987. The activity patterns of the Pyrenean desman Galemys pyrenaicus (Insectivora: Talpidae), as determined under natural conditions. Journal of Zoology 213: 95-106.

Tüxen R. and Oberdorfer E. 1958. Eurosiberische Phanerogamengesellschaften Spaniens. Veröffentlichungen des Geobotanischen Institutes Rübel 32: 1-328.

Whitaker J. O. and French T. W. 1984. Foods of six species of sympatric shrews from New Brunswick. Canadian Journal of Zoology 62: 622-626.

Wołk K. 1976. The winter food of the European water-shrew. Acta Theriologica 21: 117-129.

Yalden D. W. 1981. The occurrence of the pigmy shrew Sorex minutus on moorland, and the implications for its presence in Ireland. Journal of Zoology 195: 147-156.

Received 5 August 1997, accepted 30 October 1998. 